Article

\title{
Regulated Mycotoxin Occurrence and Co-Occurrence in Croatian Cereals
}

\author{
Marija Kovač ${ }^{1}$ D, Mateja Bulaić ${ }^{2}$, Ante Nevistić ${ }^{2}$, Tomislav Rot $^{2}$, Jurislav Babić ${ }^{3} \mathbb{D}$, Mario Panjičko $^{4}$,

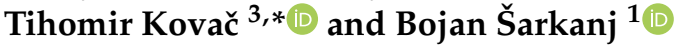

check for updates

Citation: Kovač, M.; Bulaić, M. Nevistić, A.; Rot, T.; Babić, J.; Panjičko, M.; Kovač, T.; Šarkanj, B. Regulated Mycotoxin Occurrence and Co-Occurrence in Croatian Cereals. Toxins 2022, 14, 112. https://doi.org/10.3390/ toxins 14020112

Received: 13 January 2022 Accepted: 1 February 2022 Published: 2 February 2022

Publisher's Note: MDPI stays neutral with regard to jurisdictional claims in published maps and institutional affiliations.

Copyright: (C) 2022 by the authors. Licensee MDPI, Basel, Switzerland. This article is an open access article distributed under the terms and conditions of the Creative Commons Attribution (CC BY) license (https:// creativecommons.org/licenses/by/ $4.0 /)$.
1 Department of Food Technology, University North, Trg dr. Žarka Dolinara 1, 48000 Koprivnica, Croatia; marija.kovac@unin.hr (M.K.); bsarkanj@unin.hr (B.Š.)

2 Inspecto Ltd., Industrijska Zona Nemetin, Vukovarska Cesta 239b, 31000 Osijek, Croatia; mateja.bulaic@inspecto.hr (M.B.); ante.nevistic@inspecto.hr (A.N.); tomislav.rot@inspecto.hr (T.R.)

3 Faculty of Food Technology, Josip Juraj Strossmayer University of Osijek, Franje Kuhača 18, 31000 Osijek, Croatia; jbabic@ptfos.hr

4 CROTEH-Sustainable Technologies Development Centre Ltd., Dragutina Golika 63, 10000 Zagreb, Croatia; mario.panjicko@croteh.eu

* Correspondence: tihomir.kovac@ptfos.hr; Tel.: +385-31-224-341

\begin{abstract}
A total of 209 samples of various cereal crops (maize, wheat, barley, rye and oats) grown in Croatian fields during 2016 and 2017 were collected to analyze and determine the occurrence and co-occurrence of EU regulated mycotoxins in cereals (AFB1, AFB2, AFG1, AFG2, DON, FB1, FB2, ZEA T-2, HT-2 and OTA). The analysis, performed by a validated confirmatory LC-MS/MS method based on a dilute and shoot principle, highlighted Fusarium mycotoxins as the main contaminants, often co-occurring in samples from both years (50.0\% in 2016 and 33.7\% in 2017). DON was found to be the most frequent mycotoxin, present in $72.5 \%$ of the 2016 samples and $32.6 \%$ of the 2017 samples, while maize proved to be the most contaminated cereal type of both years with FUM as the most abundant mycotoxins, with an average concentration of $1180 \mu \mathrm{g} / \mathrm{kg}$. Moderate temperatures with periods of high humidity favored the accumulation of DON in wheat samples instead of other Fusarium mycotoxins, while similar conditions favored maize contamination with FUM. A total of $8.3 \%$ of all the 2016 harvest samples and $7.9 \%$ of the 2017 harvest samples were assessed as non-compliant, containing mycotoxins in concentrations higher than the levels set by the EU legislation for food.
\end{abstract}

Keywords: EU regulated mycotoxins; cereals; co-occurrence; weather conditions; LC-MS/MS

Key Contribution: The (co-)occurrence data for all 11 mycotoxins regulated in cereals by the EU legislation provide a clearer insight on the profile of mycotoxin contamination of samples from all Croatian counties, together with the impact of weather conditions. The large number of co-occurring mycotoxin combinations highlights the necessity of the constant and continuous monitoring of mycotoxin levels to ensure food safety in a changing climate.

\section{Introduction}

Mycotoxins, secondary fungal metabolites of low-dose toxicity, are unambiguous food and feed contaminants, able to enter the food chain at any point from the field to fork chain. Cereal crop contamination with toxigenic fungi and consequently mycotoxins can occur in fields, before or after harvest, during crop manipulation and storage [1,2], thus endangering the world's still most important source of food [2]. According to the data of the Croatian Bureau of Statistics (https:/ / www.dzs.hr, accessed on 20 January 2022), cereals represent about $60 \%$ of all sown land in Croatia. A total cereal production, including the 2 most represented agricultural crops, wheat and maize, amounts for over 3,000,000 $t$, giving a yield of up to 6.0 and $9.0 \mathrm{t} / \mathrm{ha}$, respectively. Other cereal crop types, such as barley, oats and 
rye, are far less cultivated, however they are still significant for agricultural production, contributing to roughly $400,000 \mathrm{t}$.

The most important mycotoxin producers are species of the Aspergillus, Fusarium, Alternaria and Penicillium genera [3-6], each of them having favorable conditions for growth and toxin production. For example, the Aspergillus species generally require low water activity and high temperatures, while the Fusarium species mostly prefer higher water activity and moderate temperature range [1,7]. Therefore, mycotoxin presence in cereals is greatly influenced by weather conditions, including air humidity and temperature, but is also influenced by crop cultivation measures, such as chemical treatment, harvest and storage practices, affecting the grain kernels' quality (e.g., mechanical damage) [2,8-10].

Mycotoxins are considered to be one of the most important diet risks, causing diseases, mycotoxicoses, in both humans and animals [5,11,12]. Therefore, their levels in certain foodstuff and feedstuff are regulated within the European Union (EU) legislation, via the Commission Regulation (EC) No 1881/2006 [13], Commission Recommendation 2013/165/EU [14], Commission Recommendation 2006/576/EC [15] and Directive 2002/32/EC [16], setting the maximum permitted/indicative levels. For agricultural production in general and cereal production, specifically, aflatoxins (AFT)-B1 (AFB1), B2 (AFB2), G1 (AFG1) and G2 (AFG2), deoxynivalenol (DON), fumonisins (FUM)-B1 (FB1) and -B2 (FB2), zearalenone (ZEA), T-2 and HT-2 toxins and ochratoxin A (OTA) are the most significant regulated mycotoxins.

Climate change effects, such as a long-term change in temperature, precipitation and atmospheric $\mathrm{CO}_{2}$ concentrations, have an enormous impact on the incidence and the types of hazards contaminating food [17]. For example, they are leading to an unexpected (increased or reduced) risk of mycotoxin contamination of crops, affecting the cereals based on a geographical distribution, toxigenic fungi and their secondary metabolites [18]. According to the predictions, under the influence of climate change factors, pests and pathogens, including toxigenic fungi, move towards the poles at a speed of about three kilometers per year, causing latitudinal shifts in species distributions [19]. Thus, a higher incidence of Claviceps and Fusarium species is expected in Northern Europe, so far characteristic of Central Europe, while a higher Penicillium and Aspergillus species and AFT incidence, so far characteristic of Southern Europe, is expected in Central Europe [20,21]. Furthermore, climate change factors may affect mycotoxin contamination by altering the mycotoxin prevalence among the same fungal species, or by altering the relative amount of free and modified mycotoxin forms. In addition, they may have an indirect impact related to increased drought stress, insect damage to plants, or changes in crop phenology, such as changes in the flowering time and grain maturation, and all of these factors combined affect the mycotoxin production [5,22-25].

Taking all that into account, mycotoxin concentrations need to be regularly monitored, ensuring the food safety in a changing climate, contributing to public health. To the best of our knowledge, there is a lack of a comprehensive research on the occurrence and cooccurrence of all legally regulated mycotoxins in Croatian cereals. Considering the abovementioned, together with the (varying) weather impacts on mycotoxin incidence [10,26-33], the aim of our study is to investigate the occurrence and the co-occurrence of all EU regulated mycotoxins in unprocessed Croatian cereals, as well as to establish the correlation between the found mycotoxin concentrations and weather features, i.e., rainfall and air temperature, during the two-year study period, in all Croatian counties. Moreover, the obtained data on the incidence of analyzed regulated mycotoxins in cereals from the 2016 and 2017 harvest were used to create heat maps of mycotoxin incidence, and to review grain contamination levels from each Croatian county.

\section{Results and Discussion}

\subsection{Mycotoxin Occurrence and Co-Occurrence in Cereals}

The samples of various cereals grown in Croatian fields during 2016 and 2017 were contaminated with all of the regulated and analyzed fungal metabolites. Fusarium mycotox- 
ins proved to be the most common contaminants, found in all the samples in concentrations above LOD. In both analyzed harvest years, 2016 and 2017, DON was found to be the most frequent mycotoxin, appearing in $72.5 \%$ and $32.6 \%$ of all cereal samples, respectively. In 2016 , the highest concentration of DON was found in maize amounting to $4902 \mu \mathrm{g} / \mathrm{kg}$, while the average value of all positive cereal samples was $595 \mu \mathrm{g} / \mathrm{kg}$, similar to the average value of the 2017 samples when the mean value was $510 \mu \mathrm{g} / \mathrm{kg}$. However, the highest measured concentration for the 2017 samples was $2408 \mu \mathrm{g} / \mathrm{kg}$, found in wheat. The concentrations of EU regulated mycotoxins in all the cereal samples from 2016 and all the cereal samples from the 2017 harvest obtained in this study using the dilute and shoot LC-MS/MS method are presented in Table 1. The obtained mycotoxin occurrence data on the individual crop types from 2016 and from 2017 are shown in Tables 2 and 3.

Table 1. Mycotoxin occurrence in Croatian cereals of harvests from 2016 and 2017.

\begin{tabular}{|c|c|c|c|c|c|c|}
\hline \multirow[b]{2}{*}{ Analyte } & \multicolumn{2}{|c|}{$2016(n=120)$} & \multicolumn{2}{|c|}{$2017(n=89)$} & \multirow{2}{*}{$\begin{array}{c}\text { LOD } \\
\mu \mathrm{g} / \mathrm{kg}\end{array}$} & \multirow{2}{*}{$\begin{array}{c}\mathrm{LOQ} \\
\mu \mathrm{g} / \mathrm{kg}\end{array}$} \\
\hline & $\mathrm{F} \%$ & $\begin{array}{c}\text { Mean } \pm \text { SD } \\
\mu \mathrm{g} / \mathrm{kg}\end{array}$ & $\mathrm{F} \%$ & $\begin{array}{c}\text { Mean } \pm \text { SD } \\
\mu \mathrm{g} / \mathrm{kg}\end{array}$ & & \\
\hline AFB1 & n.d. & - & 3.4 & $9.0 \pm 7.5$ & 0.3 & 1.0 \\
\hline AFB2 & n.d. & - & 2.3 & $2.5 \pm 2.8$ & 0.15 & 0.5 \\
\hline AFG1 & n.d. & - & 2.3 & $11.3 \pm 13.3$ & 0.3 & 1.0 \\
\hline AFG2 & n.d. & - & 1.1 & 2.2 & 0.15 & 0.5 \\
\hline DON & 72.5 & $595 \pm 971$ & 32.6 & $510 \pm 579$ & 61 & 200 \\
\hline ZEA & 35.8 & $217 \pm 484$ & 5.6 & $1050 \pm 2295$ & 9 & 30 \\
\hline FB1 & 42.5 & $1063 \pm 1516$ & 23.6 & $724 \pm 1566$ & 46 & 150 \\
\hline FB2 & 32.5 & $280 \pm 395$ & 15.7 & $292 \pm 543$ & 46 & 150 \\
\hline $\mathrm{T}-2$ & 16.7 & $12 \pm 17$ & 10.1 & $13 \pm 9$ & 3 & 10 \\
\hline HT-2 & 45.0 & $8 \pm 8$ & 31.5 & $22 \pm 36$ & 3 & 10 \\
\hline OTA & n.d. & - & 4.5 & $154 \pm 307$ & 0.3 & 1.0 \\
\hline
\end{tabular}

n-number of samples; F\%-frequency, number of positive samples with a mycotoxin concentration above LOD; SD—standard deviation; LOD/LOQ_limit of detection/quantification and n.d.—not detected (below LOD).

Table 2. Occurrence of regulated mycotoxins in Croatian cereal samples from the 2016 harvest.

\begin{tabular}{|c|c|c|c|c|c|c|}
\hline \multirow[b]{2}{*}{ Analyte } & \multicolumn{2}{|c|}{ Maize $(n=61)$} & \multicolumn{2}{|c|}{ Wheat $(n=57)$} & \multicolumn{2}{|c|}{ Barley $(n=2)$} \\
\hline & $\mathrm{F} \%(n)$ & $\begin{array}{c}\text { Mean Conc. } \\
\mu \mathrm{g} / \mathrm{kg} \\
\text { (Min.-Max. } \\
\text { Conc.) }\end{array}$ & $\mathrm{F} \%(n)$ & $\begin{array}{c}\text { Mean Conc. } \\
\mu \mathrm{g} / \mathrm{kg} \\
\text { (Min.-Max. } \\
\text { Conc.) }\end{array}$ & $\mathrm{F} \%(n)$ & $\begin{array}{c}\text { Mean Conc. } \\
\mu \mathrm{g} / \mathrm{kg} \\
\text { (Min.-Max. } \\
\text { Conc.) }\end{array}$ \\
\hline AFB1 & n.d. & n.d. & n.d. & n.d. & n.d. & n.d. \\
\hline AFB2 & n.d. & n.d. & n.d. & n.d. & n.d. & n.d. \\
\hline AFG1 & n.d. & n.d. & n.d. & n.d. & n.d. & n.d. \\
\hline AFG2 & n.d. & n.d. & n.d. & n.d. & n.d. & n.d. \\
\hline DON & $78.7(48)$ & $865(68-4902)$ & $68.4(39)$ & $263(63-867)$ & n.d. & n.d. \\
\hline FB1 & $83.6(51)$ & 1062 (61-9344) & n.d. & n.d. & n.d. & n.d. \\
\hline FB2 & $65.6(40)$ & $58(49-2442)$ & n.d. & n.d. & n.d. & n.d. \\
\hline ZEA & $73.8(43)$ & $221(10-2068)$ & n.d. & n.d. & n.d. & n.d. \\
\hline $\mathrm{T}-2$ & $32.8(20)$ & $12(3-73)$ & n.d. & n.d. & n.d. & n.d. \\
\hline HT-2 & $88.5(54)$ & $8(3-41)$ & n.d. & n.d. & n.d. & n.d. \\
\hline OTA & n.d. & n.d. & n.d. & n.d. & n.d. & n.d. \\
\hline
\end{tabular}

n-number of samples; F\%—frequency, number of positive samples with mycotoxin conc. above LOD—limit of detection; and n.d.- not detected. 
Table 3. Occurrence of regulated mycotoxins in Croatian cereal samples from the 2017 harvest.

\begin{tabular}{|c|c|c|c|c|c|c|c|c|c|c|}
\hline \multirow[b]{2}{*}{ Analyte } & \multicolumn{2}{|c|}{ Maize $(n=23)$} & \multicolumn{2}{|c|}{ Wheat $(n=47)$} & \multicolumn{2}{|c|}{ Barley $(n=7)$} & \multicolumn{2}{|c|}{ Rye $(n=6)$} & \multicolumn{2}{|c|}{ Oats $(n=6)$} \\
\hline & $\mathbf{F} \%(n)$ & $\begin{array}{c}\text { Mean Conc. } \\
\mu \mathrm{g} / \mathrm{kg} \\
\text { (Min.-Max.) }\end{array}$ & $\mathbf{F} \%(n)$ & $\begin{array}{c}\text { Mean Conc. } \\
\mu \mathrm{g} / \mathrm{kg} \\
\text { (Min.-Max.) }\end{array}$ & $\mathrm{F} \%(n)$ & $\begin{array}{c}\text { Mean Conc. } \\
\mu \mathrm{g} / \mathrm{kg} \\
\text { (Min.-Max.) }\end{array}$ & $\mathrm{F} \%(n)$ & $\begin{array}{c}\text { Mean Conc. } \\
\mu \mathrm{g} / \mathrm{kg} \\
\text { (Min.-Max.) }\end{array}$ & $\mathrm{F} \%(n)$ & $\begin{array}{c}\text { Mean Conc. } \\
\mu \mathrm{g} / \mathrm{kg} \\
\text { (Min.-Max.) }\end{array}$ \\
\hline AFB1 & $8.7(2)$ & $5.5(1.2-9.7)$ & $2.1(1)$ & 16.2 & n.d. & n.d. & n.d. & n.d. & n.d. & n.d. \\
\hline AFB2 & $4.4(1)$ & 0.5 & $2.1(1)$ & 4.4 & n.d. & n.d. & n.d. & n.d. & n.d. & n.d. \\
\hline AFG1 & $4.4(1)$ & 1.7 & $2.1(1)$ & 20.9 & n.d. & n.d. & n.d. & n.d. & n.d. & n.d. \\
\hline AFG2 & n.d & n.d & $2.1(1)$ & 2.2 & n.d. & n.d. & n.d. & n.d. & n.d. & n.d. \\
\hline DON & $30.4(7)$ & $484(72-1156)$ & $42.6(20)$ & $474(68-2408)$ & n.d. & n.d. & $33.3(2)$ & 957 (309-1605) & $<\mathrm{LOD}$ & $<\mathrm{LOD}$ \\
\hline FB1 & $91.3(21)$ & $724(52-7350)$ & n.d & n.d & n.d. & n.d. & n.d. & n.d. & n.d. & n.d. \\
\hline FB2 & $60.9(14)$ & $292(47-2139)$ & n.d & n.d & n.d. & n.d. & n.d. & n.d. & n.d. & n.d. \\
\hline ZEA & $13.0(3)$ & $26(17-43)$ & n.d & n.d & n.d. & n.d. & $20.0(1)$ & 17 & $16.7(1)$ & 5155 \\
\hline $\mathrm{T}-2$ & $17.4(4)$ & $10(4-27)$ & n.d & n.d & n.d. & n.d. & $33.3(2)$ & $8(7-9)$ & $50.0(3)$ & $20(17-22)$ \\
\hline HT-2 & $34.8(8)$ & $18(5-154)$ & $23.4(11)$ & $4(3-7)$ & $14.3(1)$ & 3 & $33.3(2)$ & $139(32-245)$ & $100.0(6)$ & $49(6-120)$ \\
\hline OTA & n.d & n.d & $8.5(4)$ & $153.7(0.3-614)$ & n.d & n.d & n.d & n.d & n.d & n.d \\
\hline
\end{tabular}

n-number of samples; F\%-frequency, number of positive samples with mycotoxin conc. above LOD—limit of detection; and n.d.-not detected.

A total of 17 cereal samples (10 harvested in 2016 and 7 harvested in 2017) did not comply with the permitted values of mycotoxins for food presented in the Commission Regulation (EC) no. 1881/2006 [13]. One sample (maize) from 2016 and two samples (wheat and oats) from 2017 did not even comply with the permitted values for animal feed set by the Commission Recommendation 2006/576/EC [15]. An overview of non-compliant samples, with the stated counties of origin, is given in Table 4 . The most contaminated cereal type from 2016 and 2017 was maize, with FB1 being the most common mycotoxin (contaminating $85.7 \%$ of all the maize samples), followed by HT-2 (73.8\%), DON $(65.5 \%)$, FB2 (64.3\%), ZEA (54.8\%), T-2 (28.6\%), AFB1 (2.4\%), and AFB2 and AFG1 (1.2\%). Mycotoxin co-occurrence was found in $50.0 \%$ of all the 2016 samples (98.4\% of all the maize samples), containing 2 or more mycotoxins. The highest co-occurrence was observed for Fusarium mycotoxins, DON, FB1, FB2, ZEA, T-2 and HT-2, which were contained in $26.2 \%$ of all the the maize samples. FB1 and FB2 in maize samples were the most co-occurring mycotoxins in the 2017 samples, followed by DON and HT- 2 in wheat samples, giving a total of $33.7 \%$ of all the analyzed samples containing 2 or more mycotoxins. An overview of all the co-occurring mycotoxin combinations found in cereals from the 2016 and 2017 harvests is shown in Table 5.

Mycotoxin occurrence data analysis revealed the statistically significant difference in the AFT $(p=0), \operatorname{FB} 1(p=0.042), \operatorname{FUM}(p=0.041)), \mathrm{T}-2(p=0.038)$ and OTA $(p=0)$ distribution between the harvest years 2016 and 2017, unlike for other tested mycotoxins, for which no statistically significant difference (DON $(p=0.740)$, FB2 $(p=0.445)$, ZEA $(p=0.578)$ and HT- $2(p=0.139))$ was found. A comparison of the variability of mycotoxin contamination between the individual crops showed a statistically significant difference in the occurrence of DON $(p=0.002)$ and HT-2 $(p=0.038)$ between maize and wheat, as well as a statistically significant difference in the HT-2 concentration $(p=0.002)$ between wheat and oats, which was expected, given the focus of legislation [14] on the HT-2 toxin (T-2/HT-2 sum) in oats, distinguishing this type of cereal from others. The obtained statistical analysis data are summarized and presented in box-plot diagrams for both years and the analyzed mycotoxins in Appendix A (Figures A1-A5).

Data on mycotoxin occurrence and co-occurrence in Croatian cereals reported by other authors for harvest seasons 2016 and 2017 are limited; however, the data that are available for the relevant years agree with the data of the study conducted in this work. Kovač et al. (2021) [2] conducted a multicontaminant analysis of maize and wheat grown in Croatian fields in 2016, including regulated mycotoxin occurrence determination. Fusarium mycotoxins were found to be the most significant secondary metabolites, with DON being the most frequent, present in $73.7 \%$ of samples, while AFT and OTA were not detected. The analysis also revealed $8.5 \%$ of cereal samples non-compliant to the EU legislation for food regarding mycotoxins. Sunic et al. (2021) [34] investigated Fusarium mycotoxins levels, including regulated DON and ZEA, in the unprocessed wheat from the seasons in 2019/2020 from 
two locations (Vukovar-Syrmia and Osijek-Baranja counties), as a part of the study of the impact of Fusarium head blight disease on different wheat varieties. The found data showed a low contamination of naturally infected wheat with DON and ZEA (all below EU limits), but also found higher concentrations in locations with higher precipitation (from VukovarSyrmia County). Research of regulated and unregulated Fusarium mycotoxins in barley varieties from the period 2016-2018, conducted by Habschied et al. (2019) [28], showed a generally low incidence and found significantly lower concentrations of regulated Fusarium mycotoxins (DON, FB1, T-2 and HT-2), compared to the EU legislation, e.g., the found average levels of DON for 2016, 2017 and 2018 were $73 \mu \mathrm{g} / \mathrm{kg}, 83 \mu \mathrm{g} / \mathrm{kg}$ and $51 \mu \mathrm{g} / \mathrm{kg}$, respectively. The incidence of T-2 and HT-2 toxins in unprocessed cereals (oats, maize, barley and wheat) during 2017 and 2018 were investigated by Kiš et al. (2021) [10]. The lowest incidence of T-2/HT-2 toxins was observed in wheat (19.2\%), while the highest was observed in oats $(70.0 \%)$ with the highest mean concentration of $88 \pm 631 \mu \mathrm{g} / \mathrm{kg}$. The vary of T-2/HT-2 toxin concentrations between the production years 2017 and 2018 was not statistically significant and found T-2/HT-2 levels were generally lower than the EU indicative levels. The occurrence of major Fusarium mycotoxins, including DON and ZEA, was investigated by Španić et al. (2019) [27] in wheat varieties from seasons 2015/2016 and 2016/2017, to search the correlation between Fusarium head blight disease and mycotoxin occurrence. The results showed 100\% DON occurrence in the used control grain samples (non-inoculated wheat samples), with an average value of $70 \mu \mathrm{g} / \mathrm{kg}$, while ZEA was not found in any of the analyzed control samples.

Table 4. Non-compliant cereal samples from the harvests of 2016 and 2017.

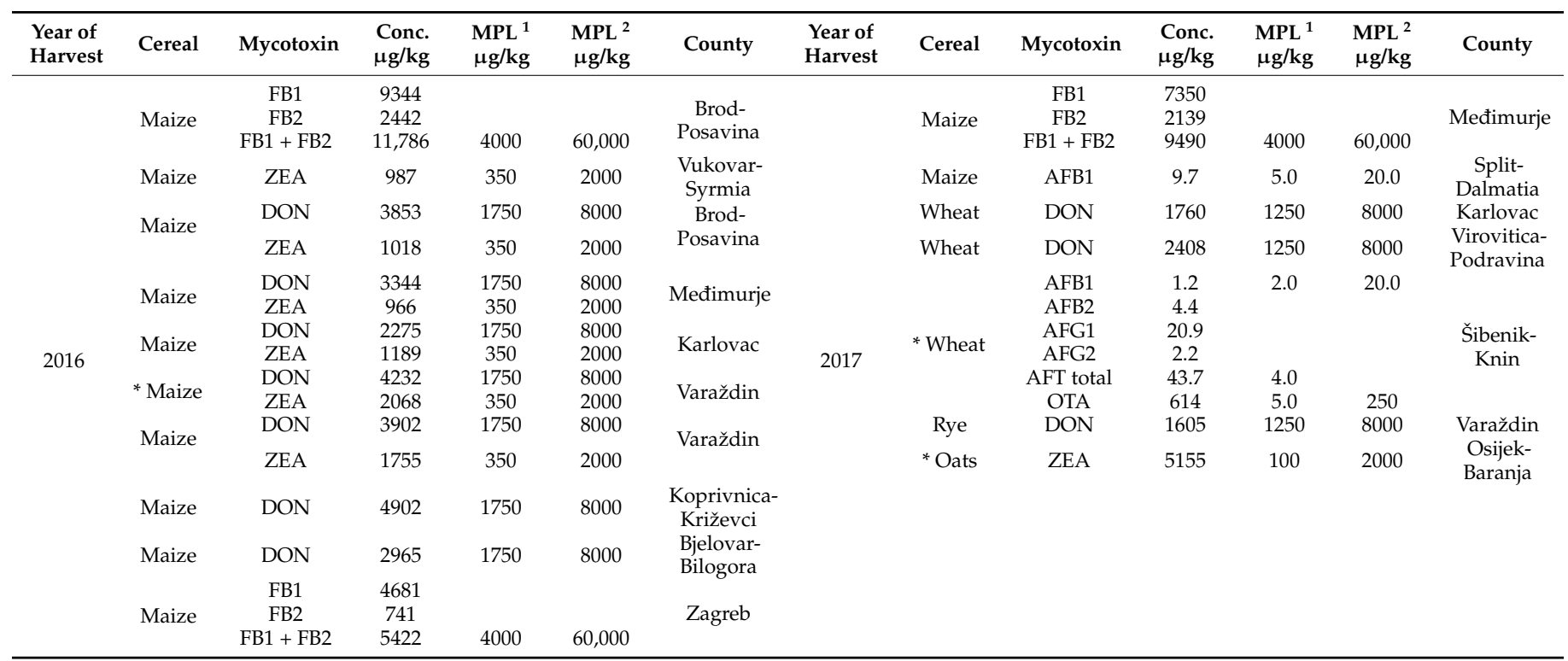

${ }^{1}$ Maximum permitted levels for certain mycotoxins in food according to the Commission Regulation (EC) No $1881 / 2006 ;{ }^{2}$ maximum permitted levels for certain mycotoxins in feed according to Directive 2002/32/EZ and the Commission Recommendation 2006/576/EC; * non-compliant samples according to the legislation for food ${ }^{1}$ and for feed ${ }^{2}$.

Table 5. Combinations of co-occurring mycotoxins found in Croatian cereals for the harvests from 2016 and 2017.

\begin{tabular}{|c|c|c|c|c|c|c|c|c|c|}
\hline \multicolumn{4}{|l|}{2016} & \multicolumn{6}{|c|}{2017} \\
\hline Mycotoxin Co-Occurrence & Maize & Wheat & Barley & Mycotoxin Co-Occurrence & Maize & Wheat & Barley & Rye & Oats \\
\hline $\mathrm{DON}+\mathrm{FB} 1+\mathrm{FB} 2+\mathrm{ZEA}+\mathrm{T}-2+\mathrm{HT}-2$ & 16 & & & $\mathrm{FB} 1+\mathrm{FB} 2$ & 8 & & & & \\
\hline $\mathrm{FB} 1+\mathrm{FB} 2+\mathrm{ZEA}+\mathrm{HT}-2$ & 9 & & & $\mathrm{AFB} 1+\mathrm{AFB} 2+\mathrm{FB} 1+\mathrm{FB} 2$ & 1 & & & & \\
\hline $\mathrm{DON}+\mathrm{FB} 1+\mathrm{FB} 2+\mathrm{ZEA}+\mathrm{HT}-2$ & 8 & & & $\mathrm{AFB} 1+\mathrm{AFG} 1+\mathrm{DON}+\mathrm{FB} 1+\mathrm{FB} 2$ & 1 & & & & \\
\hline $\mathrm{DON}+\mathrm{FB} 1+\mathrm{ZEA}+\mathrm{HT}-2$ & 7 & & & $\mathrm{DON}+\mathrm{FB} 1+\mathrm{FB} 2$ & 1 & & & & \\
\hline
\end{tabular}


Table 5. Cont.

\begin{tabular}{|c|c|c|c|c|c|c|c|c|c|}
\hline \multicolumn{4}{|l|}{2016} & \multicolumn{6}{|c|}{2017} \\
\hline Mycotoxin Co-Occurrence & Maize & Wheat & Barley & Mycotoxin Co-Occurrence & Maize & Wheat & Barley & Rye & Oats \\
\hline $\mathrm{DON}+\mathrm{FB} 1+\mathrm{FB} 2+\mathrm{HT}-2$ & 3 & & & $\mathrm{DON}+\mathrm{FB} 1+\mathrm{FB} 2+\mathrm{ZEA}$ & 1 & & & & \\
\hline $\mathrm{DON}+\mathrm{FB} 1+\mathrm{FB} 2+\mathrm{ZEA}$ & 3 & & & $\mathrm{DON}+\mathrm{FB} 1+\mathrm{FB} 2+\mathrm{ZEA}+\mathrm{HT}-2$ & 1 & & & & \\
\hline FB1 + HT-2 & 3 & & & $\mathrm{DON}+\mathrm{FB} 1+\mathrm{T}-2+\mathrm{HT}-2$ & 1 & & & & \\
\hline $\mathrm{DON}+\mathrm{ZEA}+\mathrm{HT}-2$ & 2 & & & $\mathrm{DON}+\mathrm{FB} 1+\mathrm{ZEA}+\mathrm{HT}-2$ & 1 & & & & \\
\hline $\mathrm{FB} 1+\mathrm{FB} 2+\mathrm{HT}-2$ & 2 & & & $\mathrm{FB} 1+\mathrm{FB} 2+\mathrm{HT}-2$ & 1 & & & & \\
\hline $\mathrm{DON}+\mathrm{FB} 1+\mathrm{FB} 2$ & 1 & & & $\mathrm{FB} 1+\mathrm{FB} 2+\mathrm{T}-2$ & 1 & & & & \\
\hline $\mathrm{DON}+\mathrm{FB} 1+\mathrm{FB} 2+\mathrm{T}-2+\mathrm{HT}-2$ & 1 & & & $\mathrm{FB} 1+\mathrm{FB} 2+\mathrm{T}-2+\mathrm{HT}-2$ & 1 & & & & \\
\hline $\mathrm{DON}+\mathrm{FB} 1+\mathrm{T}-2$ + HT-2 & 1 & & & $\mathrm{FB} 1+\mathrm{T}-2$ + HT-2 & 1 & & & & \\
\hline $\mathrm{DON}+\mathrm{FB} 1+\mathrm{ZEA}+\mathrm{T}-2+\mathrm{HT}-2$ & 1 & & & DON + HT-2 & & 3 & & & \\
\hline $\mathrm{DON}+\mathrm{ZEA}$ & 1 & & & $\mathrm{AFB} 1+\mathrm{AFB} 2+\mathrm{ZEA}$ & & 1 & & & \\
\hline $\mathrm{FB} 1+\mathrm{FB} 2$ & 1 & & & $\mathrm{DON}+\mathrm{HT}-2$ + OTA & & 1 & & & \\
\hline \multirow[t]{5}{*}{$\mathrm{ZEA}+\mathrm{T}-2+\mathrm{HT}-2$} & 1 & & & DON + OTA & & 1 & & & \\
\hline & & & & $\mathrm{DON}+\mathrm{T}-2+\mathrm{HT}-2$ & & & & 1 & \\
\hline & & & & $\mathrm{DON}+\mathrm{ZEA}+\mathrm{T}-2+\mathrm{HT}-2$ & & & & 1 & \\
\hline & & & & T-2 + HT-2 & & & & & 2 \\
\hline & & & & $\mathrm{ZEA}+\mathrm{T}-2+\mathrm{HT}-2$ & & & & & 1 \\
\hline Number of samples & 60 & & & Number of samples & 19 & 6 & & 2 & 3 \\
\hline$\%$ of certain cereal type & 98.4 & & & $\%$ of certain cereal type & 82.6 & 12.8 & & 33.3 & 50.0 \\
\hline$\%$ of all cereals & 50.0 & & & $\%$ of all cereals & 21.3 & 6.7 & & 2.2 & 3.4 \\
\hline
\end{tabular}

Mycotoxin incidence in Croatian cereals of earlier harvest seasons was better investigated. Pleadin et al. (2017a) [35] studied the occurrence of AFB1, OTA, ZEA, DON and FUM in samples of unprocessed cereals harvested in 2015. Maize was found to be the most contaminated cereal with $93.9 \%$ positive samples for DON, $100 \%$ for ZEA, $93.9 \%$ for FUM, $16.2 \%$ for OTA and $10.8 \%$ for AFB1. A total of $46.0 \%$ of the maize samples, $4.0 \%$ of wheat samples, $8.0 \%$ of barley samples and $11.0 \%$ of rye samples did not comply with the EU legislation requirements. As a part of Fusarium head blight disease research, Španić et al. (2018) [26] conducted a study on wheat varieties from seasons 2014/2015. Naturally contaminated wheat contained certain Fusarium mycotoxins, primarily DON, occurring in $64.0 \%$ of the analyzed wheat samples. The presence of DON, ZEA, FUM and T-2 toxin in cereals (maize, wheat, barley and oats) harvested in 2011 was investigated by Pleadin et al. (2013) [31]. Maize was proved to be the most contaminated cereal type, with DON as the most occurring mycotoxin (in $52.5 \%$ of samples), followed by ZEA (40.5\%), FUM (37.5\%) and T-2 toxin (33.0\%). The authors associated the relatively low mycotoxin contamination with the very warm and dry weather during the observation period, which is supported by the studies $[29,30]$ conducted on cereals from the year 2010, which abounded in rain and cold weather, revealing the significant contamination of the analyzed samples with Fusarium mycotoxins.

Furthermore, high air temperature and low amounts of precipitation were correlated to the high occurrence of AFB1 in cereal samples harvested in the years 2009-2013, and in products thereof [32,33], emphasizing the importance of the geographical origin of the crops, i.e., the weather conditions.

The obtained data also conform to the mycotoxin occurrence and co-occurrence studies from nearby/Balkan countries, with a climate similar to Croatia. In the Serbian study conducted by Radić et al. (2021) [36], it was shown that the growing season had an impact on Fusarium mycotoxin occurrence in maize; generally higher levels of certain Fusarium mycotoxins were detected in 2016, compared to the 2017 samples, due to increased humidity. Among the analyzed Fusarium metabolites in maize, FUM were found to be the most frequent. Stanciu et al. (2019) [37] performed a study on trichothecene and ZEA presence in Romanian wheat from the 2015 harvest season. The highest overall frequency was registered for DON, and the authors correlated the mycotoxin concentration with the precipitation and temperature values during anthesis and the preharvest period. Cereal samples from Bosnia and Herzegovina were investigated by Pleadin et al. (2017b) [38] studying the occurrence of certain Fusarium mycotoxins. Among the analyzed unprocessed 
cereals (maize, wheat, barley), maize was the most contaminated, containing DON in $85.2 \%$, ZEA in $73.0 \%$ and FUM in $66.9 \%$ of the samples. Higher mycotoxin levels determined from the 2014 samples, compared to the samples from 2013 and 2015, were linked to extreme humidity observed during the cereal growth and harvesting periods [37].

\subsection{Weather Conditions and Mycotoxin Concentrations in Cereals}

Given the above, mycotoxin biosynthesis is greatly influenced by climatic conditions, humidity and temperature, contributing to the mycotoxigenic fungi colonization and mycotoxin production $[1,7,10,39]$. The plant is generally most susceptible to contamination during the flowering period; in the case of maize, the plant is most susceptible to contamination in late July and early August (the anthesis and the silking period), when Aspergillus fungi and consequently AFT contamination is more likely to occur if extreme drought takes place. In addition, the rainy periods during September and October can cause the contamination of maize with Fusarium fungi and mycotoxins. In wheat and other spring crops, the end of May and the beginning of June are critical, since extremely rainy periods favor Fusarium fungi contamination [26,27]. Figure 1 shows the sowing, contamination and harvest periods of certain cereal crops.

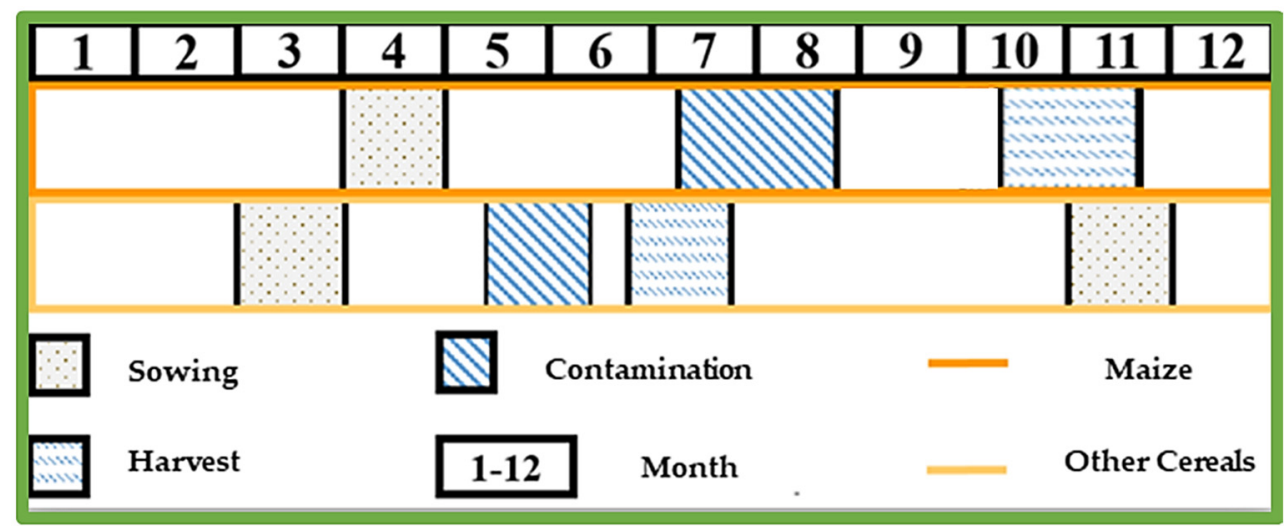

Figure 1. Sowing, contamination and harvest periods for certain cereal crops.

Relatively low average levels or the absence of found mycotoxins in wheat and other spring crops from both 2016 and 2017 can be explained by the unfavorable weather conditions during crop flowering, generally characterized by relatively mild temperatures and low amounts of precipitation. According to the publicly available meteorological data, temperature conditions in May and June of both years were normal to very warm, while precipitation conditions were normal to wet, both not deviating significantly from the multiyear average. The incidence of DON in wheat samples (68.4\% in 2016 and 42.6\% in 2017) instead of other Fusarium mycotoxins, is likely to be caused by moderate temperatures with periods of high humidity that helped certain Fusarium fungi contamination and DON accumulation [40], which is confirmed by the general absence or low contamination of cereals by ZEA. The sporadic high concentration of ZEA found in the oat sample (5155 $\mathrm{\mu g} / \mathrm{kg}$, non-compliant sample) from Osijek-Baranja County was probably caused by somewhat colder (normal) temperature conditions during May 2017, compared to the rest of the country, as well as by improper storage, since other samples from the same county were within the EU permitted levels. Moreover, the average monthly air temperatures, mostly below the multi-year average in October 2016, may be the cause of the significant ZEA production of Fusarium species and maize contamination in the 2016 harvest samples. Weather conditions, i.e., temperature and precipitation, during September and October 2016 and 2017 favored the production of FUM and thus the significant contamination of maize (FB1 in $85.7 \%$ of all maize samples). High amounts of precipitation in October 2016, which was above the multi-year average, unlike the below-average precipitation in October 2017, may be the cause of higher FUM concentrations found in the 2016 harvest samples (FB1 
61-9344 $\mu \mathrm{g} / \mathrm{kg}$ and FB2 49-2442 $\mu \mathrm{g} / \mathrm{kg}$ ), compared to 2017 (FB1 52-7350 $\mu \mathrm{g} / \mathrm{kg}$ and FB2 $47-2139 \mu \mathrm{g} / \mathrm{kg}$ ). The high concentration of AFT found in the 2017 maize sample from the Split-Dalmatia County (AFB1 $9.7 \mu \mathrm{g} / \mathrm{kg}$ and AFB2 $0.5 \mu \mathrm{g} / \mathrm{kg}$ ) can be explained by the high temperatures during the silking period, i.e., a very warm July and extremely warm August throughout the country and drought in the southern regions, which probably favored the development of aflatoxigenic fungi and the production of AFT. For comparison, in the 2016 harvest samples, AFT was not detected in any of the analyzed samples, and according to the available meteorological data, August 2016 is characterized by normal precipitation amounts in most of the country and normal to warm temperatures that did not favor the occurrence of these secondary metabolites. Significant contamination of a wheat sample originating from Šibenik-Knin County with AFT (AFB1 $16.2 \mu \mathrm{g} / \mathrm{kg}$, AFB2 $4.4 \mu \mathrm{g} / \mathrm{kg}$, AFG1 $20.9 \mu \mathrm{g} / \mathrm{kg}$ and AFG2 $2.2 \mu \mathrm{g} / \mathrm{kg})$, but also the unusually high OTA presence $(614 \mu \mathrm{g} / \mathrm{kg})$ in the same sample, cannot be explained by weather conditions at the certain micro location, thus it can be assumed that is probably a consequence of accidental contamination due to contaminated storage space. Additionally, the presence of G group AFT (AFG1, AFG2) indicates crop contamination with $A$. parasiticus, which is not a common resident of cereal fields $[5,11,41]$.

To review the cereal contamination levels of regulated mycotoxins from each Croatian county, the obtained data were used to create heat maps of mycotoxin occurrence (AFT (AFB1, AFB2, AFG1, AFG2), DON, FUM (FB1, FB2), ZEA, T-2, HT-2, OTA) for the harvest years 2016 and 2017, and for the average of 2016-2017, presented in Figures 2-8. The range of found mycotoxin concentrations is shown using green and purple colors, representing the concentrations ranging from very low to very high. In both harvest years, 2016 and 2017, DON significantly contaminated samples from almost every Croatian county, while the highest incidence was observed in Karlovac and Varaždin counties in 2016, and Karlovac County in 2017. FUM were present in a large part of continental Croatia in the 2016 samples, with the highest found concentrations in Brod-Posavina County, while a lower incidence of FUM was recorded in the 2017 samples, with an outlier of $9490 \mu \mathrm{g} / \mathrm{kg}$ found in Međimurje County. Significant concentrations of ZEA in the 2016 harvest samples were found in the north and east of Croatia, and the highest concentrations were recorded in Varaždin and Karlovac counties. The same mycotoxin contaminated the cereals in 2017 significantly less, and the highest incidence was determined in Osijek-Baranja County. The occurrence of T-2 toxin in 2016 was the most significant in the eastern part of Croatia (Osijek-Baranja and Požega-Slavonia counties), similar to HT-2, which was found in the highest concentrations in Požega-Slavonia County. In 2017, T-2 and HT-2 most frequently appeared in the Karlovac and Koprivnica-Križevci counties, followed by Varaždin and Osijek-Baranja counties. AFT were found in only a few samples of the analyzed cereals from the 2017 harvest year, with the highest concentrations originating from Southern Croatia (Šibenik-Knin and Split-Dalmatia counties), which also contained a significant concentration of OTA. 


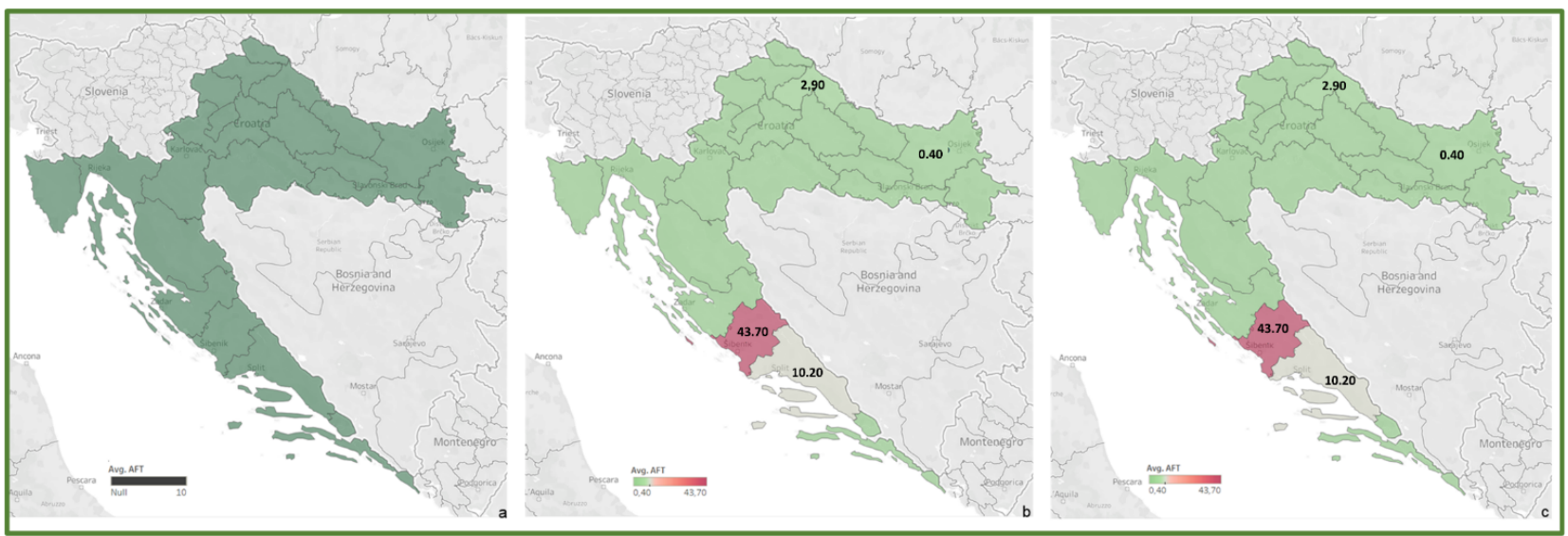

Figure 2. Heat maps of AFT occurrence in Croatian cereals from the harvests of 2016 (a), 2017 (b) and 2016-2017 (c). The range of found concentrations of AFT (legend Avg. AFT) is shown in green (low concentration) and purple (high concentration). In 2016, (a) AFT was not found, while in 2017 (b) it was found in concentrations $0.40-43.70 \mu \mathrm{g} / \mathrm{kg}$.

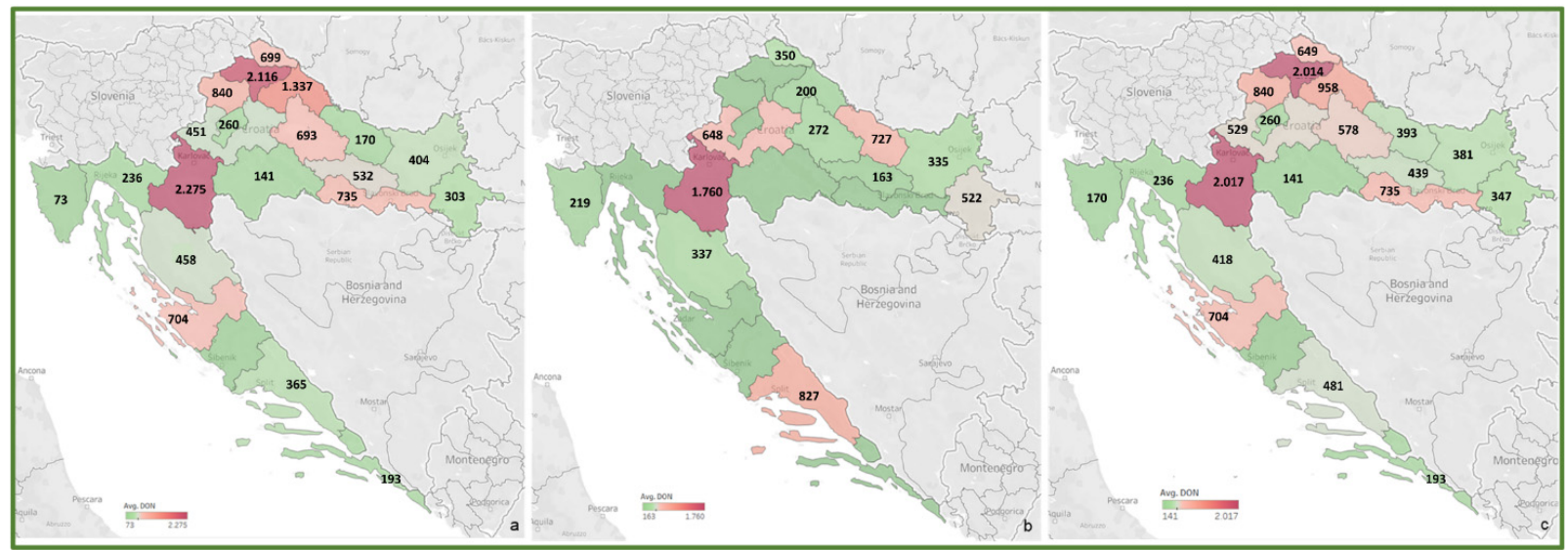

Figure 3. Heat maps of DON occurrence in Croatian cereals from the harvests of 2016 (a), 2017 (b) and 2016-2017 (c). The range of found concentrations of DON (legend Avg. DON) is shown in green (low concentration) and purple (high concentration). In 2016, (a) DON was found in concentrations 73-2275 $\mu \mathrm{g} / \mathrm{kg}$, while in 2017 (b) in concentrations $163-1760 \mu \mathrm{g} / \mathrm{kg}$.

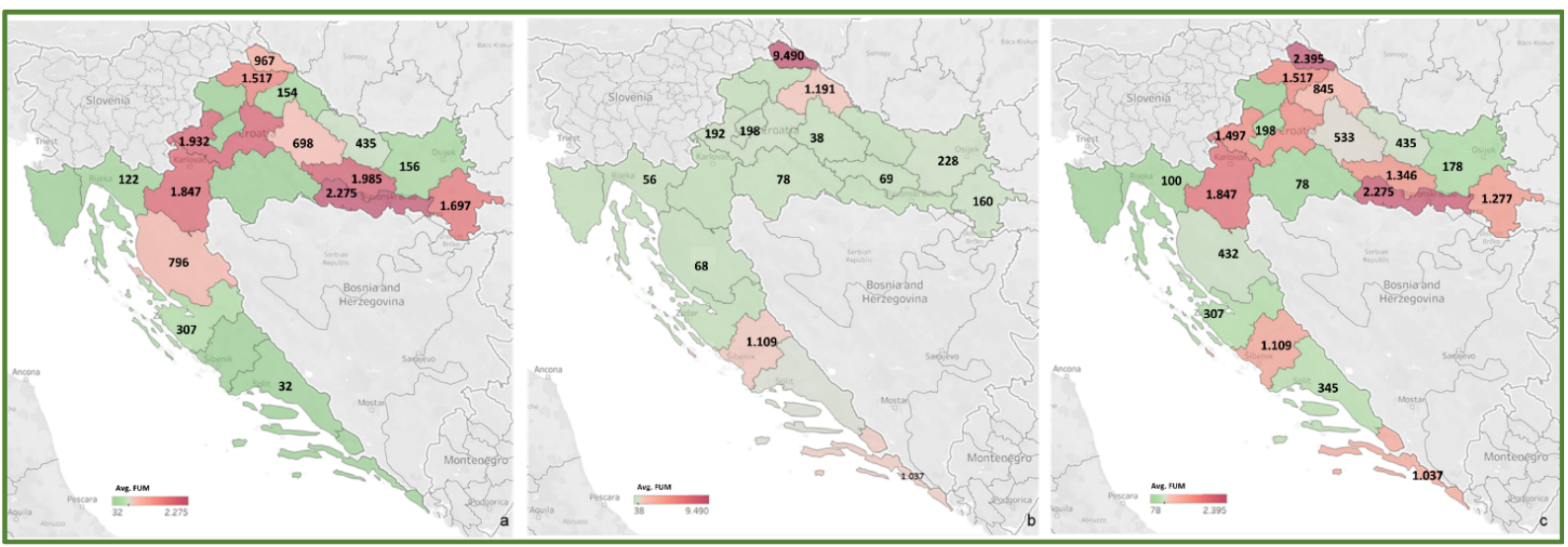

Figure 4. Heat maps of FUM occurrence in Croatian cereals from the harvests of 2016 (a), 2017 (b) and 2016-2017 (c). The range of found concentrations of FUM (legend Avg. FUM) is shown in green (low concentration) and purple (high concentration). In 2016, (a) FUM was found in concentrations $32-2275 \mu \mathrm{g} / \mathrm{kg}$, while in 2017 (b) in concentrations 38-9490 $\mu \mathrm{g} / \mathrm{kg}$. 


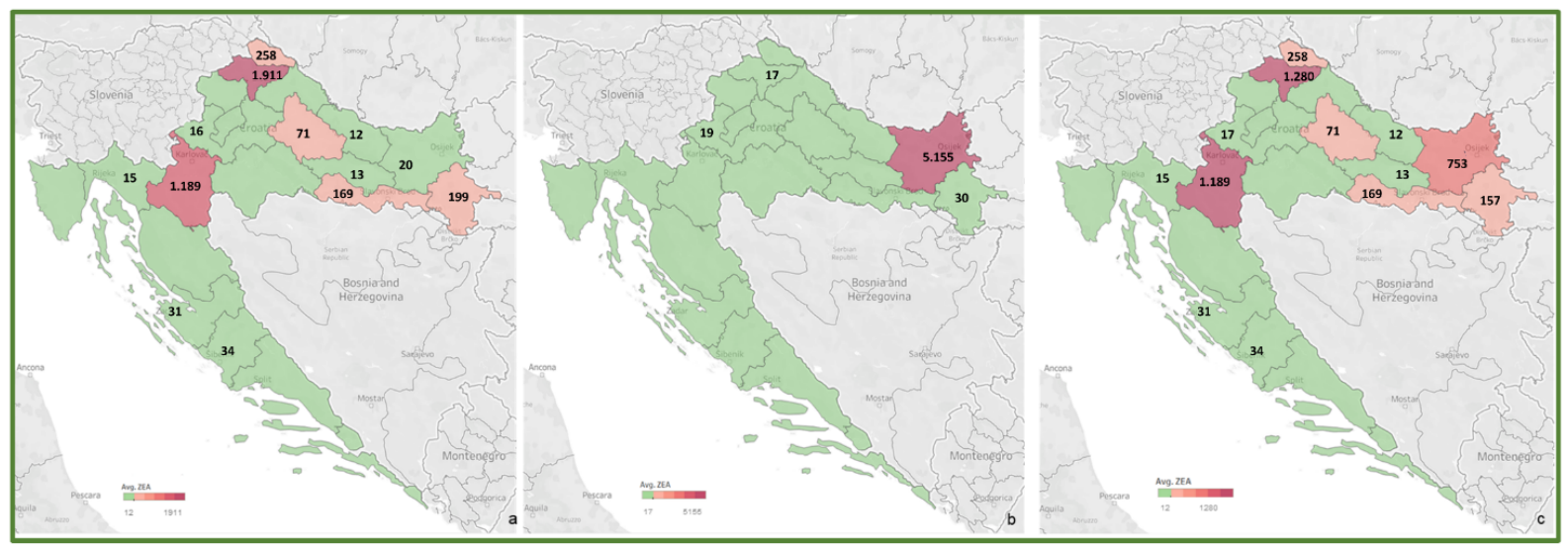

Figure 5. Heat maps of ZEA occurrence in Croatian cereals from the harvests of 2016 (a), 2017 (b) and 2016-2017 (c). The range of found concentrations of ZEA (legend Avg. ZEA) is shown in green (low concentration) and purple (high concentration). In 2016, (a) ZEA was found in concentrations 12-1911 $\mu \mathrm{g} / \mathrm{kg}$, while in 2017 (b) in concentrations 17-5155 $\mu \mathrm{g} / \mathrm{kg}$.

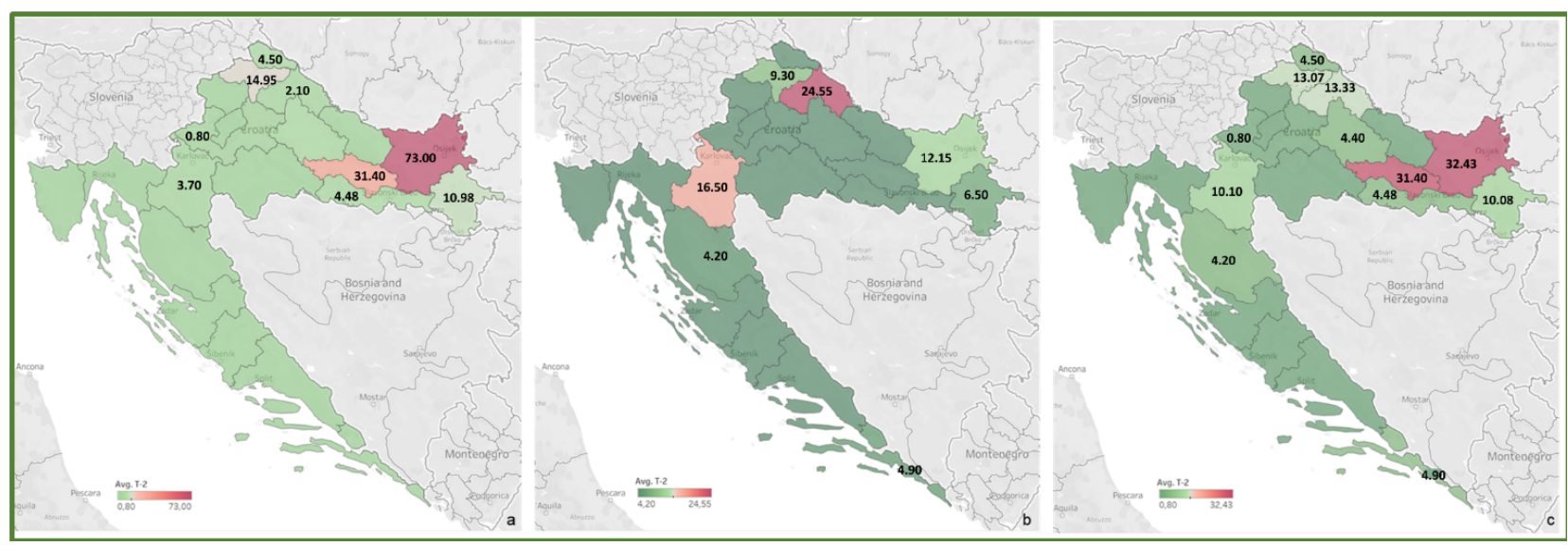

Figure 6. Heat maps of T-2 occurrence in Croatian cereals from the harvests of 2016 (a), 2017 (b) and 2016-2017 (c). The range of found concentrations of T-2 (legend Avg. T-2) is shown in green (low concentration) and purple (high concentration). In 2016, (a) T-2 was found in concentrations $0.80-73.0 \mu \mathrm{g} / \mathrm{kg}$, while in 2017 (b) in concentrations $4.20-24.55 \mu \mathrm{g} / \mathrm{kg}$.

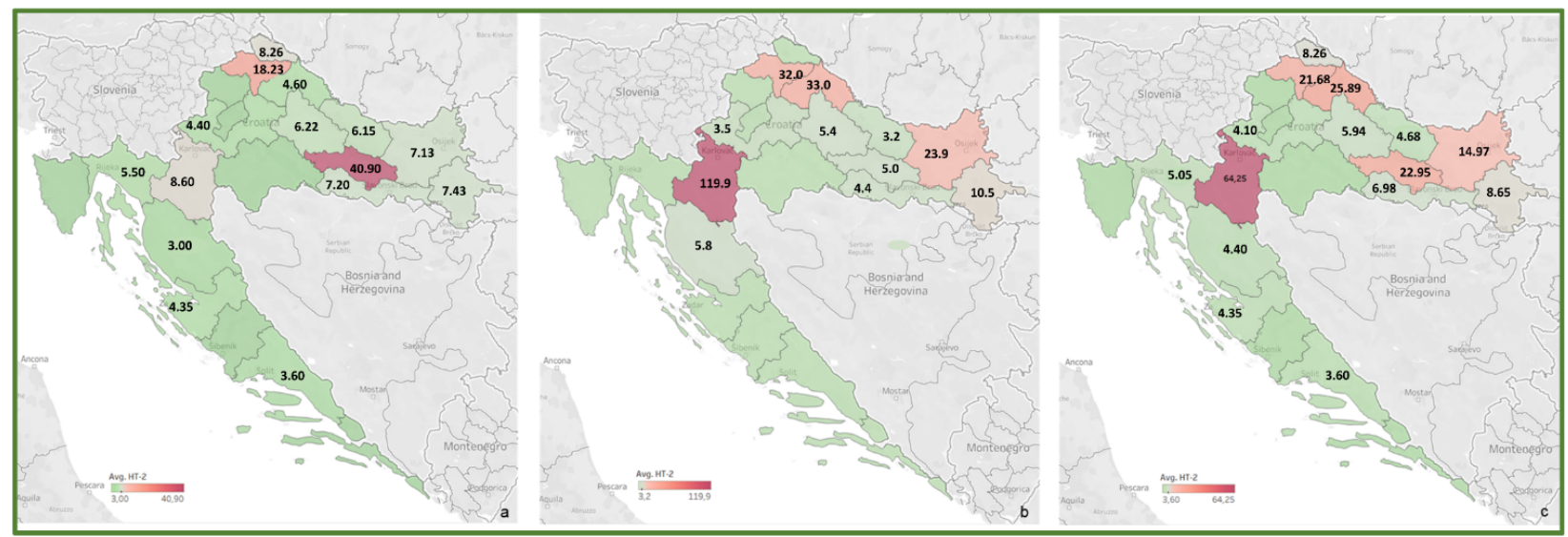

Figure 7. Heat maps of HT-2 occurrence in Croatian cereals from the harvests of 2016 (a), 2017 (b) and 2016-2017 (c). The range of found concentrations of HT-2 (legend Avg. HT-2) is shown in green (low concentration) and purple (high concentration). In 2016, (a) HT-2 was found in concentrations $3.00-40.90 \mu \mathrm{g} / \mathrm{kg}$, while in 2017 (b) in concentrations $3.2-119.9 \mu \mathrm{g} / \mathrm{kg}$. 


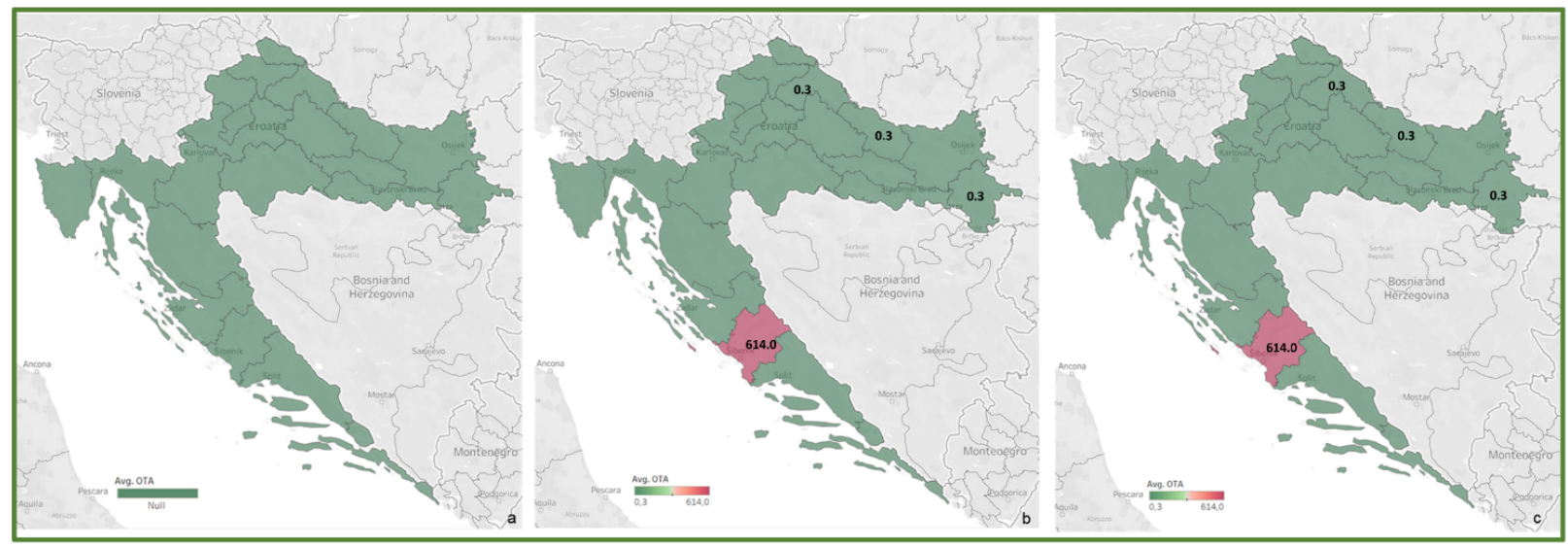

Figure 8. Heat maps of OTA occurrence in Croatian cereals from the harvests of 2016 (a), 2017 (b) and 2016-2017 (c). The range of found concentrations of OTA (legend Avg. OTA) is shown in green (low concentration) and purple (high concentration). In 2016, (a) OTA was not found, while in 2017 (b) it was found in concentrations $0.3-614 \mu \mathrm{g} / \mathrm{kg}$.

The occurrence and found concentrations of dominant Fusarium mycotoxins, DON and FUM, in cereals from 2016 and 2017 are correlated with the annual amount of precipitation at certain locations, which is the cause of significant contamination with these mycotoxins in 2016 cereals, compared to 2017. The annual amount of precipitation for 2016 at a greater number of locations was above the multi-year average, than for 2017. DON and FUM occurrences in cereals originating from Northern and Central Croatia with normal annual precipitation amounts can be explained by rainy periods during the flowering period, when crop infection by the Fusarium species occurred, while a significant incidence of AFT and OTA in crops in Southern Croatia (areas around the cities of Šibenik, Knin and Split) corresponds to dry annual precipitation amounts during 2017.

\section{Conclusions}

The research conducted in the current study provides the first comprehensive occurrence and co-occurrence data on all mycotoxins regulated in cereals by the EU legislation (AFB1, AFB2, AFG1, AFG2, DON, FB1, FB2, ZEA, T-2, HT-2 and OTA), presenting a clearer insight on the profiles of mycotoxin contamination of samples from all Croatian counties, together with the impact of weather conditions. The results highlighted Fusarium mycotoxins as the main contaminants, with DON being the most frequent in all the sampled cereal crops, while maize proved to be the most contaminated cereal type for both years. A total of $8.3 \%$ of all the harvest samples from 2016, and $7.9 \%$ of the 2017 harvest samples were non-compliant regarding the permitted levels given in the EU legislation for food. Mycotoxin co-occurrence was confirmed in 50.0\% and 33.7\% of cereal samples from 2016 and 2017, respectively, with Fusarium mycotoxin combination being the most frequent. Furthermore, the found mycotoxins and their concentrations are shown to be related to meteorological conditions during the flowering period of the plants, and the reason for the more significant contamination level of the 2016 cereals rather than 2017. Even though a relatively small percentage of the analyzed cereal samples was assessed as non-compliant to the EU legislation for food, sporadically high concentrations of certain mycotoxins, as well as a large number of co-occurring mycotoxin combinations, point out the necessity of the constant and continuous monitoring of mycotoxin levels and gathering enough data for proper toxicological studies, to ensure food safety in a world exposed to climate change.

\section{Materials and Methods}

\subsection{Sample Collection}

A total of 209 samples of unprocessed cereals (maize 84, wheat 104, barley 9, rye 6 and oats 6) grown in the Croatian fields in the years 2016 and 2017, were selected to analyze 
and determine the occurrence and co-occurrence of EU regulated mycotoxins. The samples were collected from all Croatian counties, at least one sample from each county and the rest according to the cereal type representation. The sampling was conducted in warehouses and silos in accordance with the Commission Regulation (EC) No 401/2006 [42]. To obtain a homogeneous particle size, samples prepared in test portions (10 kg per sample) were ground using a Romer RAS mill (Romer Labs, Tulln, Austria) with a sieve pore size $0.5 \mathrm{~mm}$, reduced to a laboratory subsample of $500 \mathrm{~g}$ using a Retsch Sample Splitter RT 12.5 (Retsch, Haan, Germany) and afterwards stored in a freezer at $-18^{\circ} \mathrm{C}$ pending analysis.

\subsection{Chemicals, Reagents and Standards}

All certified mycotoxin standards were supplied by Romer Labs Biopure (Romer Labs, Tulln, Austria), stored according to the manufacturer's instructions and tempered to room temperature before use. LC-MS grade acetonitrile and methanol were obtained from J.T. Baker (J.T. Baker, Deventer, The Netherlands), while LC-MS grade formic acid and ammonium format were supplied by Sigma-Aldrich (Sigma-Aldrich, St. Louis, MO, USA). Ultrapure water was generated by the Niro VV system (Nirosta d.o.o., Osijek, Croatia).

\subsection{Mycotoxins Determination}

The determination of all the 11 mycotoxins regulated in cereals by the above-mentioned EU legislation (AFB1, AFB2, AFG1, AFG2, DON, FB1, FB2, ZEA, T-2, HT-2 and OTA) was performed by a confirmatory LC-MS/MS method, based on a dilute and shoot principle, previously described by Kovač et al. (2021) [2]. The method was in-house validated according to the relevant EU legislation $[42,43]$ to fulfil the performance criteria and other requirements set for the analytical methods. For identification purposes, the relative retention time of the certain analyte had to correspond to that of the calibration solution at a tolerance of $\pm 2.5 \%$, and the relative ion intensities (quantification and confirmation ion response ratio) had to match an amount of $\pm 30 \%$ of the ion ratio in the analyte standard from the same measurement sequence, thus satisfying the criteria of the Commission Decision (EC) No. 657/2002 [43]. The external matrix-matched calibration for each cereal type was used for quantification purposes, while internal quality control was conducted by performing the recovery experiments by spiking within each sample batch, correcting the measured concentrations for recovery when outside the allowed range (90-110\%) for mycotoxins by the Commission Regulation (EC) No. 401/2006 [42]. An additional method control was carried out via participation in proficiency testing schemes in both years, in which measurements were taken and evaluated using the obtained z-scores (presented in Appendix B, Table A1), which were considered as satisfactory when within range $|\mathrm{z}| \leq \pm 2$.

\subsection{Statistical Analyses}

Statistical software packages, Statistica 13.3 (TIBCO Software Inc., Palo Alto, CA, USA) and Tableau 2019.4.5 (3 Excel 2016 (Microsoft, Redmond, WA, USA), were used for statistical data processing. In results processing, the methods of descriptive statistical analysis were used: measures of central tendency and measures of variability (range, standard deviation) calculated from the obtained measurements. The normality of the data distribution was tested by the Shapiro-Wilk W test, the homogeneity of the Levene's test variance, and a comparison between the two individual variables by the Mann-Whitney $U$ test in data not normally distributed and by the $t$-test in normally distributed data. The Spearman's correlation coefficient was used to calculate the correlation; data with $p<0.05$ values were considered statistically significantly different.

\subsection{Meteorological Data/Heat Maps of Mycotoxin Incidence}

A comparison of the type and concentration of found mycotoxins with weather conditions at individual micro locations was performed, using the data obtained from the Croatian Meteorological and Hydrological Service (publicly available at https:/ / meteo.hr, accessed on 22 December 2021) on weather conditions (average monthly air temperature, 
average monthly amount of precipitation) during the cereal growth and harvest season in the years 2016 and 2017. Heat maps of mycotoxin incidence throughout the country (representing each county) were designed using Tableau 2019.4.5 (Tableau Software, Seattle, WA, USA).

\subsection{Sample Compliance}

The compliance of the analyzed samples regarding the mycotoxins was proved by comparing the found mycotoxin concentrations with the permitted/indicative levels for mycotoxins stated in the EU legislation given by the Commission Regulation (EC) No 1881/2006 [13] and the Commission Recommendation 2013/165/EU [14] for food, and the Commission Recommendation 2006/576/EC [15] and Directive 2002/32/EC [16] for feed.

Author Contributions: Conceptualization, methodology and visualization, M.K., T.K. and B.Š.; validation, formal analysis and investigation, M.K., M.B. and T.R.; data analysis, resources and supervision, A.N., J.B. and M.P.; writing-original draft preparation, M.K.; writing-review and editing, T.K. and B.Š. All authors have read and agreed to the published version of the manuscript.

Funding: This research received no external funding.

Institutional Review Board Statement: Not applicable.

Informed Consent Statement: Not applicable.

Conflicts of Interest: The authors declare no conflict of interest.

Appendix A. Box-Plot Diagrams of Found Mycotoxins in (Certain) Cereals from the 2016/2017 Harvest Years
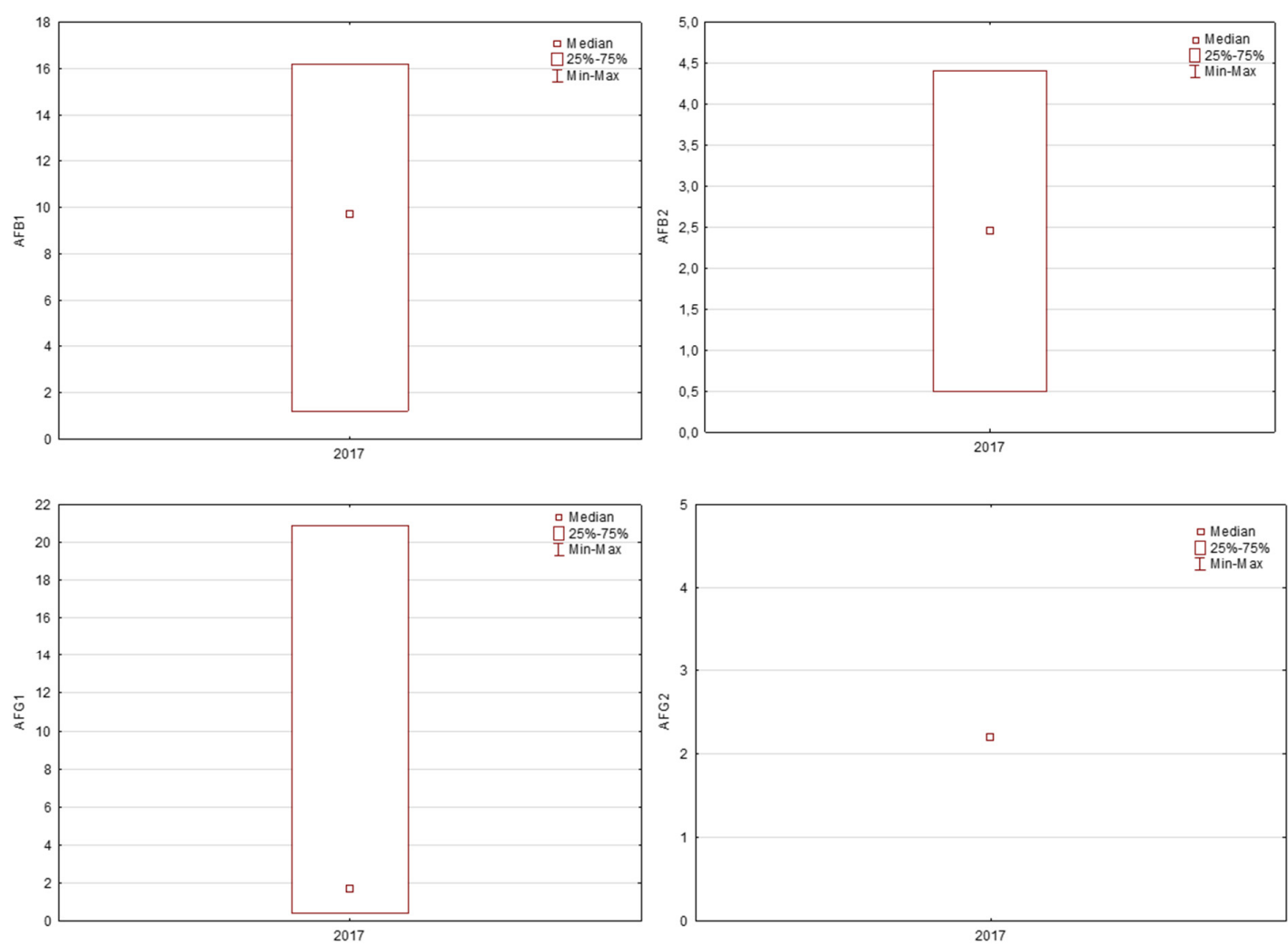

Figure A1. AFB1, AFB2, AFG1 and AFG2 in 2017 harvest cereals. 

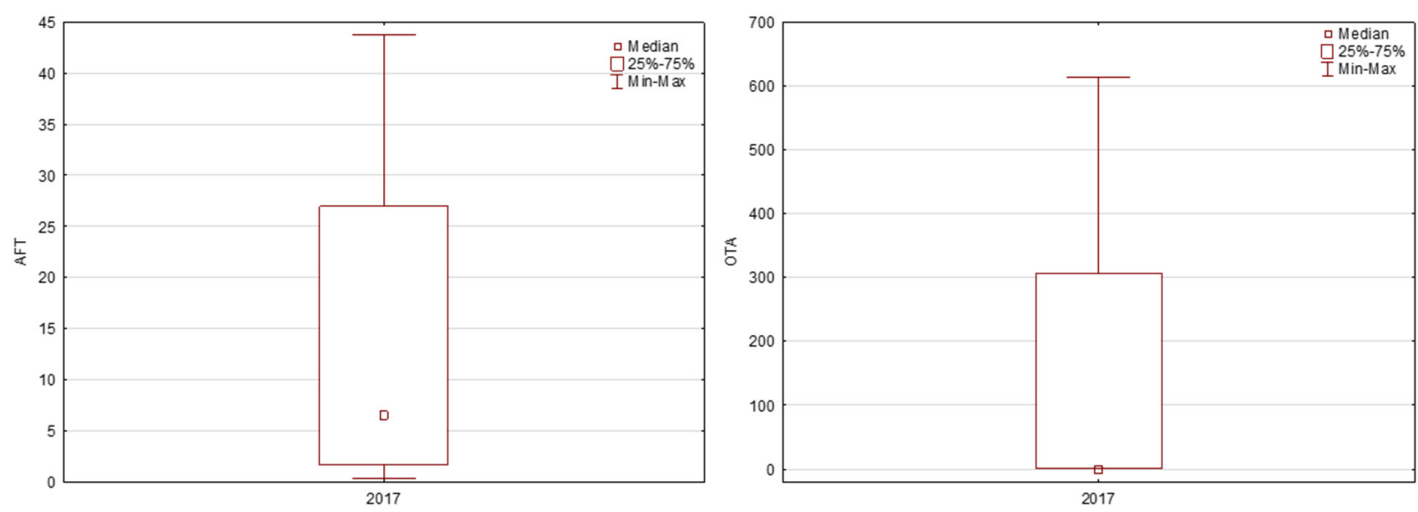

Figure A2. AFT and OTA in 2017 harvest cereals.
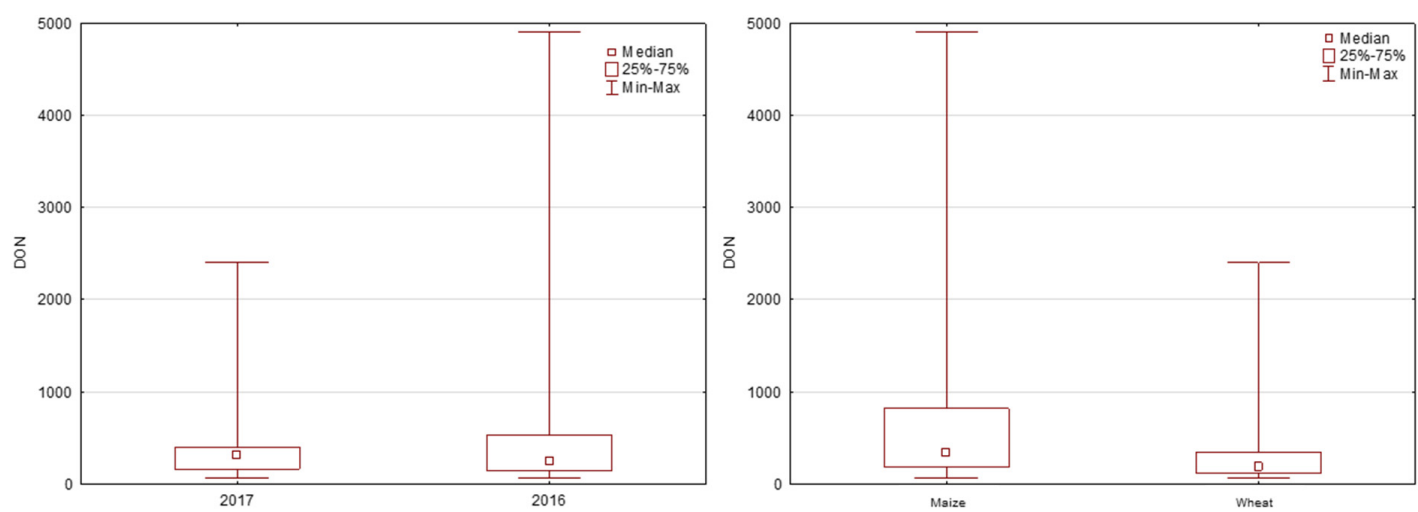

Figure A3. DON in 2016 and 2017 harvest cereals, DON in maize and wheat.
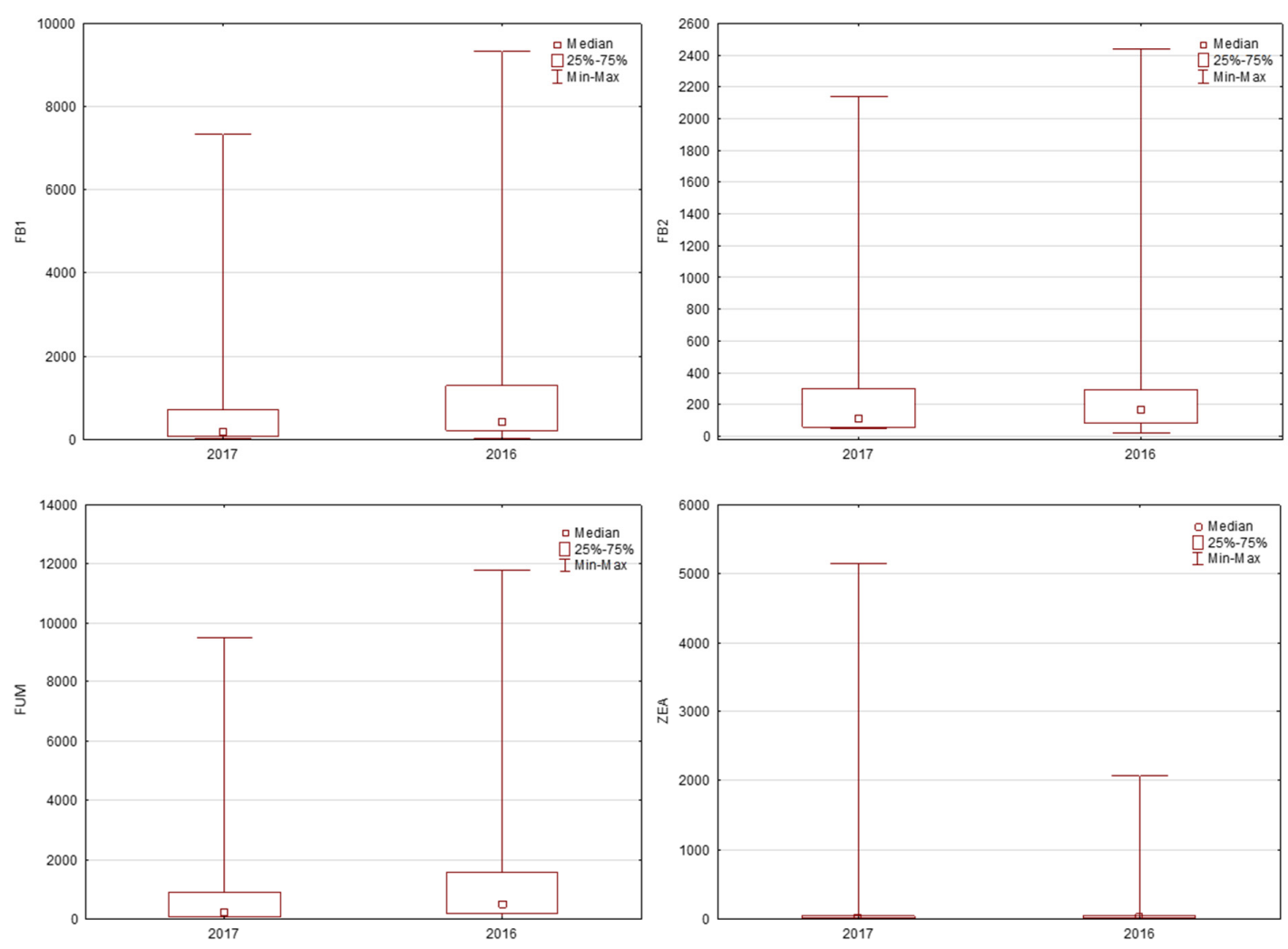

Figure A4. FUM, FB1, FB2 and ZEA in 2016 and 2017 harvest cereals. 

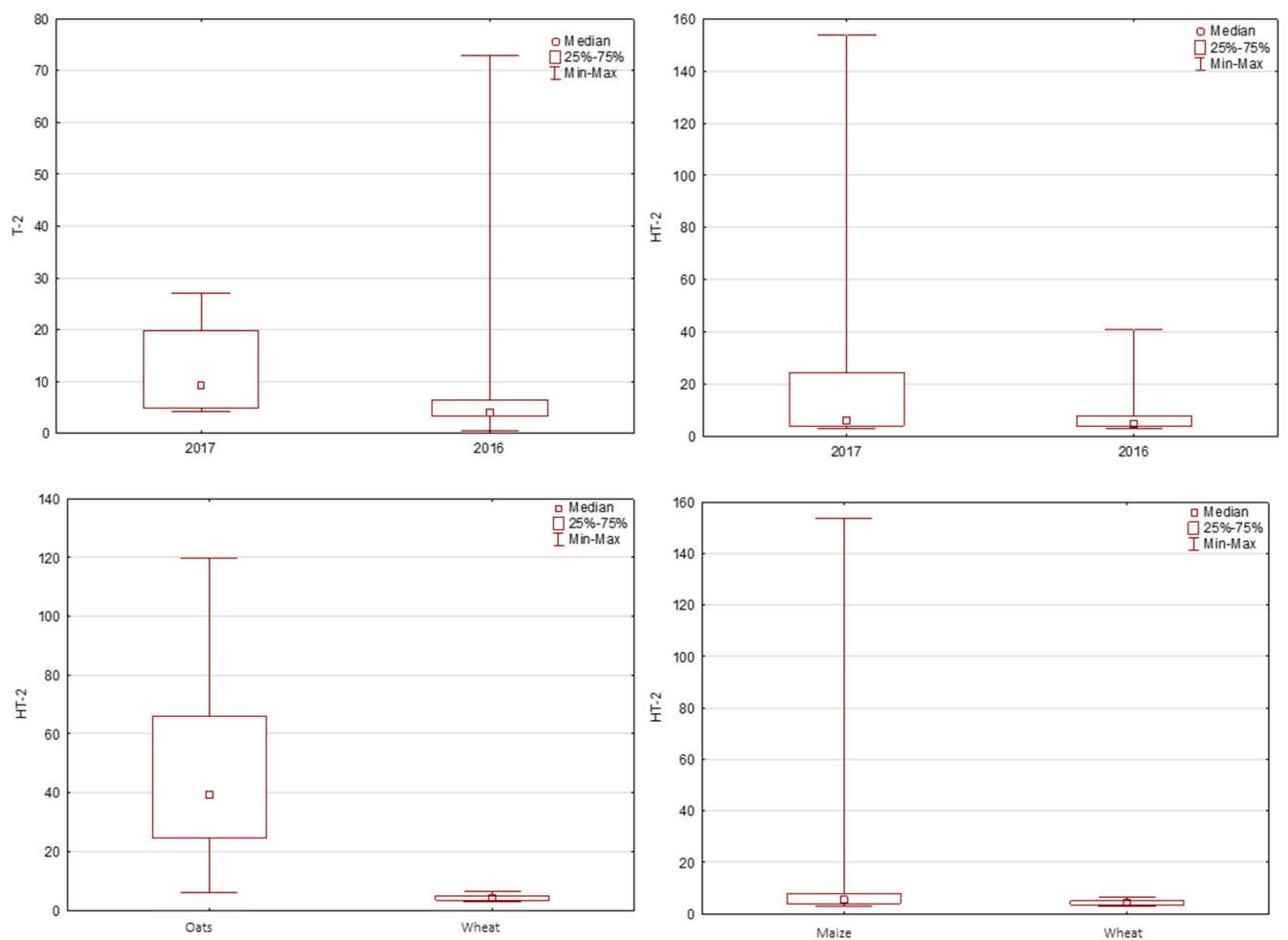

Figure A5. T-2 and HT-2 in 2016 and 2017 harvest cereals; HT-2 in oats and wheat; HT-2 in maize and wheat.

\section{Appendix B. External Method Control Carried Out via Participation in Proficiency Testing Schemes}

Table A1. Proficiency testing results for mycotoxins in cereals.

\begin{tabular}{cccc}
\hline $\begin{array}{c}\text { Proficiency Testing Scheme } \\
\text { (2017/2018) }\end{array}$ & Matrix & Analyte & Z-Score \\
\hline Romer Labs & Wheat & DON & 0.3 \\
CSSMY014-M18161DZ (2018) & & ZEA & 1.6 \\
Romer Labs & & AFB1 & -1.7 \\
& Maize & AFB2 & -1 \\
& & AFT (sum) & -1.6 \\
CSSMY017-M19411AF (2018) & FB1 & -0.4 \\
& & FB2 & -0.4 \\
& & FUM (sum) & -0.7 \\
Bipea 03-0531 (2018) & AFB1 & -1.48 \\
& & AFB2 & 0.00 \\
Romer Labs & & AFG1 & -0.08 \\
Romer Labs & AFG2 & 0.35 \\
CSSMY012-M17161DZ (2017) & Wheat & T-2 & -0.21 \\
CSSMY013-M17411A (2017) & Maize & DON & 0.15 \\
& & ZEA & 0.8 \\
& & AFB1 & -0.3 \\
& & AFB2 & -1.2 \\
Bipea 04-5131 (2017) & AFB1 & 0.4 \\
& & AFB2 & 0.00 \\
& & AFG1 & -0.25 \\
& & AFG2 & -0.20 \\
& & T-2 & -0.45 \\
& & HT-2 & 0.52 \\
& & & 0.30 \\
\hline & & &
\end{tabular}




\section{References}

1. Bhat, R.; Rai, R.V.; Karim, A.A. Mycotoxins in Food and Feed: Present Status and Future Concerns. Compr. Rev. Food Sci. Food Saf. 2010, 9, 57-81. [CrossRef]

2. Kovač, M.; Bulaić, M.; Jakovljević, J.; Nevistić, A.; Rot, T.; Kovač, T. Mycotoxins, Pesticide Residues, and Heavy Metals Analysis of Croatian Cereals. Microorganisms 2021, 9, 216. [CrossRef] [PubMed]

3. Kovač, T.; Šarkanj, B.; Crevar, B.; Kovač, M.; Lončarić, A.; Strelec, I.; Ezekiel, C.N.; Sulyok, M.; Krska, R. Aspergillus flavus NRRL 3251 growth, oxidative status, and aflatoxins production ability in vitro under different illumination regimes. Toxins 2018, 10, 528. [CrossRef] [PubMed]

4. Kovač, T.; Borišev, I.; Crevar, B.; Čačić Kenjerić, F.; Kovač, M.; Strelec, I.; Ezekiel, C.N.; Sulyok, M.; Krska, R.; Šarkanj, B. Fullerol $\mathrm{C}_{60}(\mathrm{OH})_{24}$ nanoparticles modulate aflatoxin B1 biosynthesis in Aspergillus flavus. Sci. Rep. 2018, 8, 12855. [CrossRef] [PubMed]

5. Kovač, M.; Šubarić, D.; Bulaić, M.; Kovač, T.; Šarkanj, B. Yesterday masked, today modified; what do mycotoxins bring next? Arh. Hig. Rada Toksikol. 2018, 69, 196-214. [CrossRef]

6. Kovač, T.; Šarkanj, B.; Borišev, I.; Djordjevic, A.; Jović, D.; Lončarić, A.; Babić, J.; Jozinović, A.; Krska, T.; Gangl, J.; et al. Fullerol $\mathrm{C}_{60}(\mathrm{OH})_{24}$ Nanoparticles Affect Secondary Metabolite Profile of Important Foodborne Mycotoxigenic Fungi In Vitro. Toxins 2020, 12, 213. [CrossRef]

7. Pleadin, J.; Zadravec, M.; Lešić, T.; Frece, J.; Markov, K.; Vasilj, V. Climate change-A potential threat for increasing occurrences of mycotoxins. Vet. Stanica 2020, 51, 659-671. [CrossRef]

8. Eeckhout, M.; Landschoot, S.; Deschuyffeleer, N.; De Laethauwer, S.; Haesaert, G. Guidelines for prevention and control of mould growth and mycotoxin production in cereals. In Mycohunt, Synagra. Be/Download. Ashx; European Commission: Brussels, Belgium, 2013.

9. Khodaei, D.; Javanmardi, F.; Khaneghah, A.M. The global overview of the occurrence of mycotoxins in cereals: A three-year survey. Curr. Opin. Food Sci. 2021, 39, 36-42. [CrossRef]

10. Kiš, M.; Vulić, A.; Kudumija, N.; Šarkanj, B.; Jaki Tkalec, V.; Aladić, K.; Škrivanko, M.; Furmeg, S.; Pleadin, J. A Two-Year Occurrence of Fusarium T-2 and HT-2 Toxin in Croatian Cereals Relative of the Regional Weather. Toxins 2021, 13, 39. [CrossRef] [PubMed]

11. Bennett, J.W.; Klich, M. Mycotoxins. Food Microbiol. Fundam. Front. 2003, 16, 497-516. [CrossRef]

12. Kovač, T.; Šarkanj, B.; Klapec, T.; Borišev, I.; Kovač, M.; Nevistić, A.; Strelec, I. Antiaflatoxigenic effect of fullerene $C_{60}$ nanoparticles at environmentally plausible concentrations. AMB Express 2018, 8, 14. [CrossRef] [PubMed]

13. European Commission. Commission Regulation (EC) No 1881/2006 of 19 December 2006 setting maximum levels for certain contaminants in foodstuffs. Off. J. Eur. Union 2006, 364, 5-24.

14. European Commission. Commission Recomendation of the 27 March 2013 on the presence of T-2 and HT-2 toxin in cereals and cereal products. Off. J. Eur. Union 2013, 91, 12-15.

15. European Commission. Commission Recommendation of 17 August 2006 on the presence of deoxynivalenol, zearalenone, ochratoxin A, T-2 and HT-2 and fumonisins in products intended for animal feeding. Off. J. Eur. Union 2006, $229,7-9$.

16. European Commission. Directive 2002/32/EC of the European Parliament and of the Council of 7 May 2002 on undesirable substances in animal feed. Off. J. Eur. Communities 2002, 31, 166-177.

17. Oyedele, O.A.; Akinyemi, M.O.; Kovač, T.; Eze, U.A.; Ezekiel, C.N. Food safety in the face of climate change. Croat. J. Food Sci. Technol. 2020, 12, 280-286. [CrossRef]

18. Perrone, G.; Ferrara, M.; Medina, A.; Pascale, M.; Magan, N. Toxigenic fungi and mycotoxins in a climate change scenario: Ecology, genomics, distribution, prediction and prevention of the risk. Microorganisms 2020, 8, 1496. [CrossRef]

19. Bebber, D.P.; Ramotowski, M.A.T.; Gurr, S.J. Crop pests and pathogens move polewards in a warming world. Nat. Clim. Chang. 2013, 3, 985-988. [CrossRef]

20. Battilani, P.; Rossi, V.; Giorni, P.; Pietri, A.; Gualla, A.; Van der Fels-Klerx, H.J.; Booij, C.J.H.; Moretti, A.; Logrieco, A.; Toscano, P. Modelling, predicting and mapping the emergence of aflatoxins in cereals in the eu due to climate change. EFSA Sci. Tech. Rep. 2012, 9, 223E. [CrossRef]

21. Battilani, P.; Toscano, P.; Van Der Fels-Klerx, H.J.; Moretti, A.; Leggieri, M.C.; Brera, C. Aflatoxin B1 contamination in maize in Europe increases due to climate change. Sci. Rep. 2016, 6, 24328. [CrossRef]

22. Van Der Fels-Klerx, H.J.; Liu, C.; Battilani, P. Modelling climate change impacts on mycotoxin contamination. World Mycotoxin J. 2016, 9, 717-726. [CrossRef]

23. Medina, A.; Akbar, A.; Baazeem, A.; Rodriguez, A.; Magan, N. Climate change, food security and mycotoxins: Do we know enough? Fungal Biol. Rev. 2017, 31, 143-154. [CrossRef]

24. Marček, T.; Kovač, T.; Jukić, K.; Lončarić, A.; Ižaković, M. Application of high voltage electrical discharge treatment to improve wheat germination and early growth under drought and salinity conditions. Plants 2021, 10, 2137. [CrossRef]

25. Kovač, T.; Marček, T.; Šarkanj, B.; Borišev, I.; Ižaković, M.; Jukić, K.; Lončarić, A.; Krska, T.; Sulyok, M.; Krska, R. Fullerol $\mathrm{C}_{60}(\mathrm{OH})_{24}$ nanoparticles and drought impact on wheat (Triticum aestivum $\mathrm{L}$.) during growth and infection with aspergillus flavus. J. Fungi 2021, 7, 236. [CrossRef]

26. Spanic, V.; Marcek, T.; Abicic, I.; Sarkanj, B. Effects of fusarium head blight on wheat grain and malt infected by fusarium culmorum. Toxins 2018, 10, 17. [CrossRef] 
27. Spanic, V.; Zdunic, Z.; Drezner, G.; Sarkanj, B. The pressure of fusarium disease and its relation with mycotoxins in the wheat grain and malt. Toxins. 2019, 11, 198. [CrossRef]

28. Habschied, K.; Krska, R.; Sulyok, M.; Šarkanj, B.; Krstanović, V.; Lalić, A.; Šimić, G.; Mastanjević, K. Screening of various metabolites in six barley varieties grown under natural climatic conditions (2016-2018). Microorganisms 2019, 7, 532. [CrossRef] [PubMed]

29. Pleadin, J.; Sokolović, M.; Perši, N.; Zadravec, M.; Jaki, V.; Vulić, A. Contamination of maize with deoxynivalenol and zearalenone in Croatia. Food Control 2012, 28, 94-98. [CrossRef]

30. Pleadin, J.; Zadravec, M.; Perši, N.; Vulić, A.; Jaki, V.; Mitak, M. Mould and mycotoxin contamination of pig feed in northwest Croatia. Mycotoxin Res. 2012, 28, 157-162. [CrossRef] [PubMed]

31. Pleadin, J.; Vahčić, N.; Perši, N.; Ševelj, D.; Markov, K.; Frece, J. Fusarium mycotoxins' occurrence in cereals harvested from Croatian fields. Food Control 2013, 32, 49-54. [CrossRef]

32. Pleadin, J.; Vulić, A.; Perši, N.; Škrivanko, M.; Capek, B.; Cvetnić, Ž. Annual and regional variations of aflatoxin B1 levels seen in grains and feed coming from Croatian dairy farms over a 5-year period. Food Control 2015, 47, 221-225. [CrossRef]

33. Pleadin, J.; Vulić, A.; Perši, N.; Škrivanko, M.; Capek, B.; Cvetnić, Ž. Aflatoxin B1 occurrence in maize sampled from Croatian farms and feed factories during 2013. Food Control 2014, 40, 286-291. [CrossRef]

34. Sunic, K.; Kovac, T.; Loncaric, A.; Babic, J.; Sulyok, M.; Krska, R.; Drezner, G.; Spanic, V. Fusarium secondary metabolite content in naturally produced and artificially provoked fhb pressure in winter wheat. Agronomy 2021, 11, 2239. [CrossRef]

35. Pleadin, J.; Staver, M.M.; Markov, K.; Frece, J.; Zadravec, M.; Jaki, V.; Krupić, I.; Vahčić, N. Mycotoxins in organic and conventional cereals and cereal products grown and marketed in Croatia. Mycotoxin Res. 2017, 33, 219-227. [CrossRef] [PubMed]

36. Radić, B.; Kos, J.; Janić Hajnal, E.; Malachová, A.; Krska, R.; Sulyok, M. Fusarium metabolites in maize from regions of Northern Serbia in 2016-2017. Food Addit. Contam. Part B 2021, 14, 295-305. [CrossRef]

37. Stanciu, O.; Juan, C.; Berrada, H.; Miere, D.; Loghin, F.; Mañes, J. Study on trichothecene and zearalenone presence in Romanian wheat relative to weather conditions. Toxins 2019, 11, 163. [CrossRef]

38. Pleadin, J.; Vasilj, V.; Petrovic, D.; Frece, J.; Vahcic, N.; Jahic, S.; Markov, K. Annual variations of Fusarium mycotoxins in unprocessed maize, wheat and barley from Bosnia and Herzegovina. Croat. J. Food Sci. Technol. 2017, 9, 11-18. [CrossRef]

39. Alexa, E.; Dehelean, C.A.; Poiana, M.A.; Radulov, I.; Cimpean, A.M.; Bordean, D.M.; Tulcan, C.; Pop, G. The occurrence of mycotoxins in wheat from western Romania and histopathological impact as effect of feed intake. Chem. Cent. J. 2013, 7, 99. [CrossRef]

40. Bryła, M.; Waśkiewicz, A.; Podolska, G.; Szymczyk, K.; Jędrzejczak, R.; Damaziak, K.; Sułek, A. Occurrence of 26 mycotoxins in the grain of cereals cultivated in Poland. Toxins 2016, 8, 160. [CrossRef]

41. Peraica, M.; Rašić, D. Akutne I Kronične Mikotoksikoze U Ljudi. Krmiva Čas. Hranidbi Zivotinj. Proizv. Tehnol. Krme 2012, 54, 81-87.

42. European Commission. Commission Regulation (EC) No 401/2006 of 23 February 2006 laying down the methods of sampling and analysis for the official control of the levels of mycotoxins in foodstuffs. Off. J. Eur. Union 2006, 70, 12-34.

43. European Commission. Commission Decision of 14 August 2002 implementing Council Directive 96/23/EC concerning the performance of analytical methods and the interpretation of results. Off. J. Eur. Communities 2002, 221, 8-36. 